\title{
Numerical Studies of PEM Fuel Cell with Serpentine Flow-Field for
} Sustainable Energy Use

\author{
Sang-Hoon Jang ${ }^{1}$, GiSoo Shin ${ }^{1}$, Hana Hwang ${ }^{1}$, Kap-Seung Choi ${ }^{1}$, Hyung-Man Kim ${ }^{1, *}$ \\ ${ }^{I}$ Department of Mechanical Engineering \& High Safety Vehicle Core Technology Research Center, INJE \\ University, 607 Eobang-dong, Gimhae-si, Gyongsangnam-do 621-749, Republic of Korea \\ * Corresponding author. Tel: +82 55320 3666, Fax: +82 55324 1723, E-mail: mechkhm@inje.ac.kr
}

\begin{abstract}
This paper proposes the numerical analyses on performance for PEMFC in the aspects of water management and distribution of current density were performed to compare serpentine channel flow field of 5 passes 4 turns serpentine and $25 \mathrm{~cm}^{2}$ reaction surface between with and without sub-channel at rib. Through the supplement of sub-channel flow field, the improvement of water removal characteristic inside channel was confirmed from the numerical results because the flow direction of under-rib convection is changed into the subchannel. Reacting gases supplied from entrance disperse into sub-channel flow field and electrochemical reaction occurs uniformly over the reaction surface. Therefore, it was also known that total current density distributions become uniform because retention time of reacting gases traveling to sub-channel flow field is longer than main channel. At the averaged current density of $0.6 \mathrm{~A} / \mathrm{cm}^{2}$, the results show that output power for the serpentine flow-field with sub-channel is $8.475 \mathrm{~W}$ which is decreased by about $0.35 \%$ compared with 8.505 $\mathrm{W}$ for the conventional-advanced serpentine flow-field, whereas the pressure drops on the anode and cathode side for the serpentine flow-field with sub-channel are $0.282 \mathrm{kPa}$ and $1.321 \mathrm{kPa}$ which are decreased by about $22.95 \%$ and $17.12 \%$ compared with $0.366 \mathrm{kPa}$ and $1.594 \mathrm{kPa}$ for the conventional-advanced serpentine flowfield, respectively.
\end{abstract}

Keywords: PEM Fuel Cell, Current density, Water management, Under-rib convection, Sub-channel

\section{Introduction}

Proton exchange membrane fuel cell (PEMFC) has been considered one of the most promising alternative clean power generators because of its low to zero emission, its low temperature operation, high power density, and high efficiency [1]. Currently, many researchers have studied the bipolar plate considered performance and water management in the flow channel. Kanezaki [2] and Nam [3] have found that under-rib convection flow between adjacent channels. The under-rib convection is believed to increase the reactant concentration in the under-rib regions, facilitate liquid water removal from those regions, and enable a more uniform concentration distribution, thus explaining an experimental result of good cell performance.

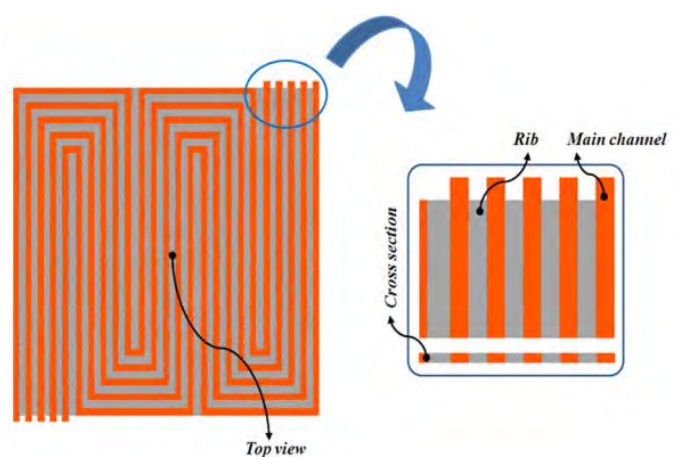

(a) case \#1

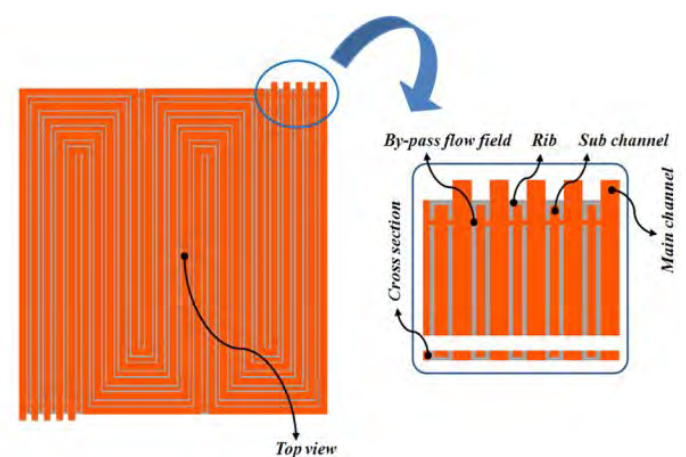

(b) case \#2

Fig. 1. Two $25 \mathrm{~cm}^{2}$ serpentine flow-field patterns; (a) case \#1(without sub-channel); (b) case \#2(with sub-channel). 
This paper proposes the numerical analyses on pe rformance for PEMFC in the aspects of water management and distribution of current density were performed to compare serpentine channel flow fields of 5-passes and 4-turns serpentine and $25 \mathrm{~cm}^{2}$ reaction surface between with and without sub-channel at rib. Two serpentine flow-field patterns are shown in Fig. 1.

\section{Numerical model}

In this study, CFD programs based on STAR-CD and ES-PEMFC were used to solve the fully coupled governing equations. The model assumes a s teady state, ideal gas properties, and homogeneous two phase flows. Assuming that liquid film is formed on the electrode surface during liquid water condensation, the Henry's law of the solubility of gases in the liquid water is used to calculate the diffusion flux, electro-osmotic drag force, and water back diffusion [4, 5]. To improve the computational accuracy, grid cells were established by equalizing the node connectivity in each component and by using the hexahedron mesh. The number of computational cells used in the model varied with complexity of the model. For the case \#1, the total cell number was 3.078 million cells, case \#2 had 3.336 million computational cells. The present numerical model was validated by grid tests and numerical simulation results on $10 \mathrm{~cm}^{2}$ serpentine with single channel flow-field PEMFC [4].

\section{Results and discussion}

The parametric studies were conducted on $25 \mathrm{c} \mathrm{m}^{2}$ serpentine channels that have the case \#1 and case \#2 configurations, all under the same operating conditions and inlet flow velocity as listed in Table 1 and Table 2. The performance-related parameters include membrane water content $(\lambda)$, net water flux per proton $(\alpha)$, pressure drop, current density. They are investigated to generate the optimum serpentine flow-field that enhances the PEMFC performance. The net water flux per proton expresses the water transport between anode and cathode. If the net water flux per proton is greater than 0 , the electro-osmotic drag is higher than the back diffusion, and water is transported from the anode to the cathode. On the other hand, the net water flux per proton is less than 0 mainly in the outlet area under the ribs, and water is transported from the cathode to the anode by the back diffusion. Back diffusion occurred due to the concentration of water on the anode is higher than on the cathode.

Table 1. Inlet conditions at Anode and Cathode.

\begin{tabular}{lc|lc}
\hline Anode & Inlet conditions & Cathode & Inlet conditions \\
\hline Gas & Hydrogen & Gas & Air \\
Stoichiometry & 1.5 & Stoichiometry & 2.0 \\
Inlet temperature $\left({ }^{\circ} \mathrm{O}\right)$ & 75 & Inlet temperature $\left({ }^{\circ} \mathrm{O}\right)$ & 75 \\
Inlet relative humidity $(\%)$ & 100 & Inlet relative humidity $(\%)$ & 100 \\
Mass fraction of hydrogen & 0.078 & Mass fraction of hydrogen & 0.169 \\
Mass fraction of water & 0.561 & Mass fraction of water & 0.274 \\
\hline
\end{tabular}

Table 2. Operating conditions at $I_{\text {ave }}=0.6 \mathrm{~A} / \mathrm{cm}^{2}$.

Operating conditions

$\% \mathrm{H}_{2}$ in reformate $\quad 75$

Exit pressure $(\mathrm{kPa})$

$\mathrm{H}_{2}$ exchange current density $\left(\mathrm{A} / \mathrm{cm}^{2}\right)$

2000

$\mathrm{O}_{2}$ exchange current density $\left(\mathrm{A} / \mathrm{cm}^{2}\right) \quad 200$

Open circuit voltage $(\mathrm{V}) \quad 0.96$

Cell temperature $\left({ }^{\circ} \mathrm{C}\right)$ 
Fig. $2 \sim$ Fig. 4 show the comparison of the membrane water contents $(\lambda)$, net water flux per proton $(\alpha)$ and current density distributions at averaged current density of $0.6 \mathrm{~A} / \mathrm{cm}^{2}$.

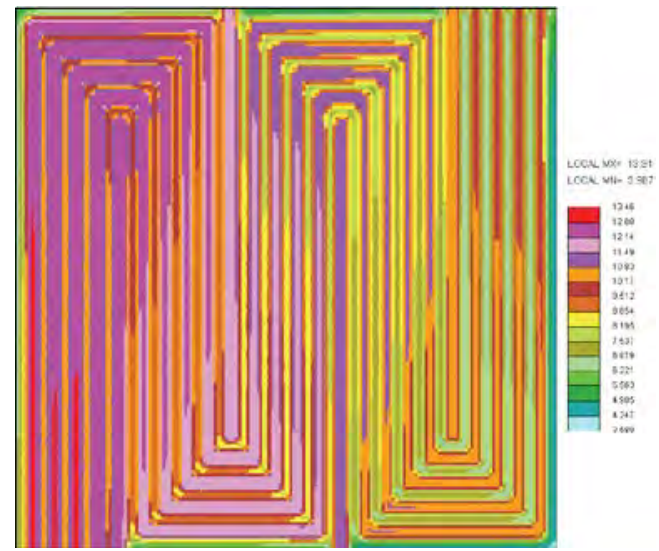

(a) case \#1

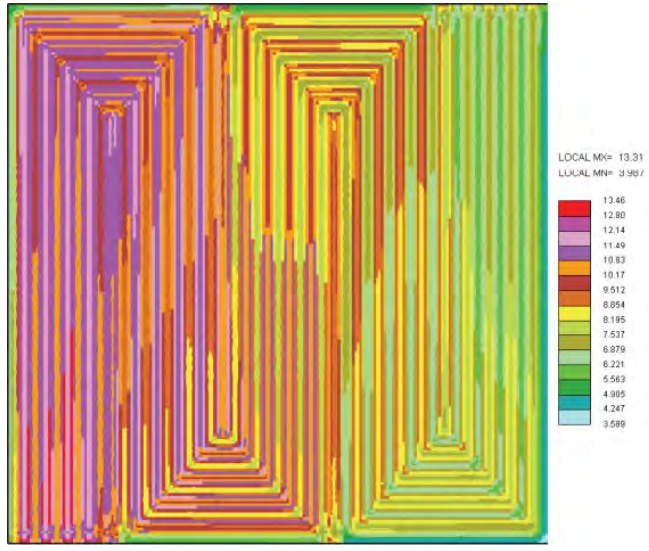

(b) case \#2

Fig. 2. Water content ( $\lambda$ ) at $I_{\text {ave }}=0.6 \mathrm{~A} / \mathrm{cm}^{2}$; (a) case \#1; (b) case \#2.

Fig. 2 shows the comparison of the membrane water contents between the case \#1 and case \#2 at the averaged current density of $0.6 \mathrm{~A} / \mathrm{cm}^{2}$. The membrane water content under the rib area is higher than that under the adjacent channel area because a lot of water produced at the cathode under the rib region can be absorbed into the membrane as shown in case \#1. On the other hand, the membrane water content of the case \#2 has smaller variation between the channel and rib than that of the case \#1 because under-rib convection flow from channel to the adjacent rib and then flow from the inlet channel to the adjacent outlet channel, and liquid water gathers and discharges into sub-channel.

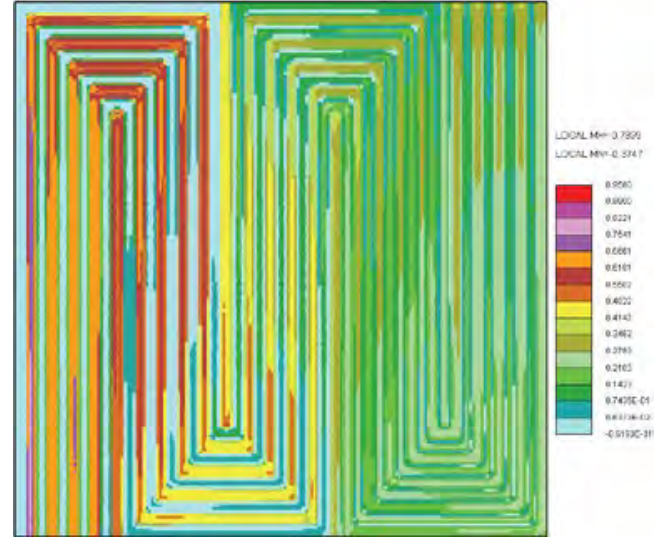

(a) case \#1

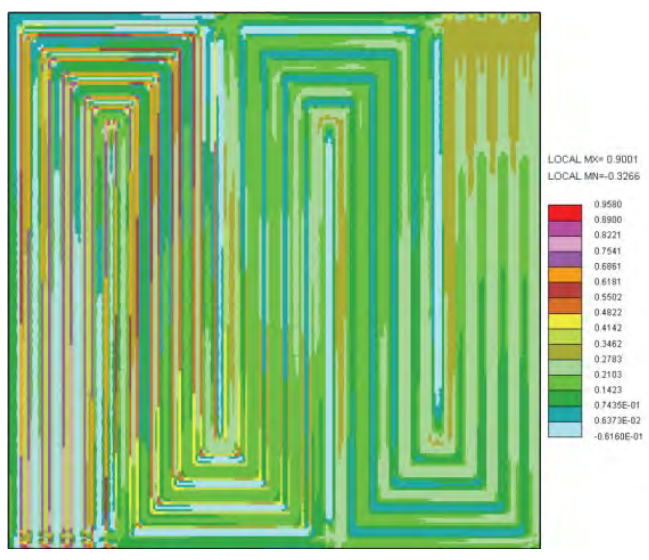

(b) case \#2

Fig. 3. Net water flux per proton ( $\alpha$ ) at $I_{\text {ave }}=0.6 \mathrm{~A} / \mathrm{cm}^{2}$; (a) case \#1; (b) case \#2.

Fig. 3 shows the comparison of the net water flux per proton between the case \#1 and case \#2 at the averaged current density of $0.6 \mathrm{~A} / \mathrm{cm}^{2}$. The net water flux per proton is greater than 0 at the ribs and that is less than 0 at the channels as shown in case \#1. The net water flux per proton is always greater than at the ribs because the hydrogen ions are transported from cathode to the anode with a lot of water. Case \#2 shows that the net water flux per proton at the ribs is lower due to sub-channel than the net water flux per proton at the channels i.e. a lot of water is transported from cathode to the anode. 


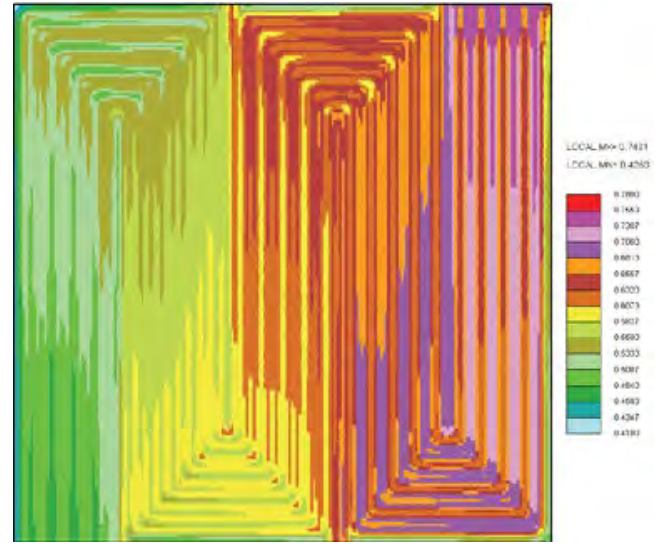

(a) case \#1

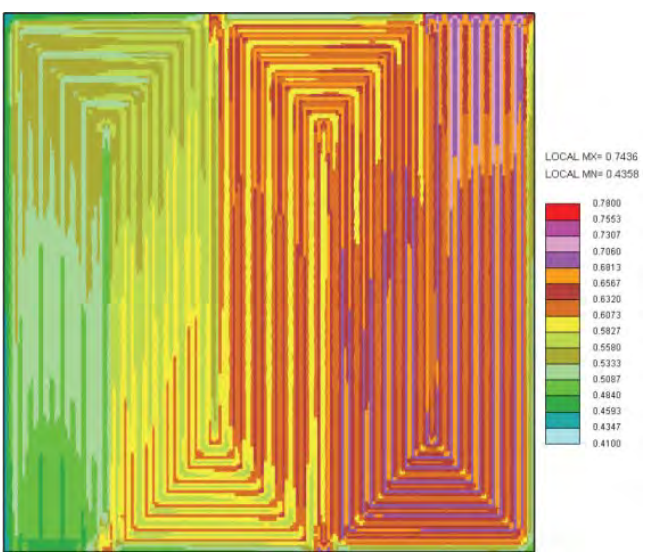

(b) case \#2

Fig. 4. Current density distributions at $I_{\text {ave }}=0.6 \mathrm{~A} / \mathrm{cm}^{2}$; (a) case \#1, case \#2.

Fig. 4 presents the comparison of the current density distributions between the case \#1 and case \#2 at the averaged current density of $0.6 \mathrm{~A} / \mathrm{cm}^{2}$. The overall distributions show that the local current density is decreasing from the inlet toward the outlet due to the consumption of the reacting gases. Through the supplement of sub channel flow field, it is shown from the results that water removal characteristic inside channel improves because the flow direction of under-rib convection is changed into the sub channel. Therefore, case \#2 shows that total current density distributions become uniform because retention time of reacting gases traveling to sub channel flow field is longer than to main channel.

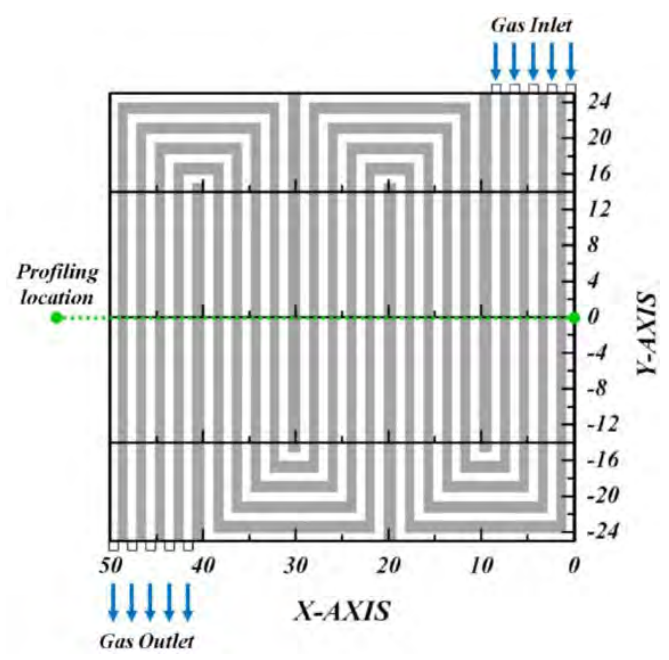

Fig. 5. Index and location of the serpentine flow-field.

Fig. 6 shows the comparison of the total pressures between the case \#1 and case \#2 at the averaged current density of $0.6 \mathrm{~A} / \mathrm{cm}^{2}$ and the same location as shown in Fig. 5. The pressure drops on the anode and cathode side for case $\# 2$ are $0.282 \mathrm{kP} \mathrm{a}$ and $1.321 \mathrm{kPa}$ which are decreased by about $22.95 \%$ and $17.12 \%$ compared with $0.366 \mathrm{kPa}$ and $1.594 \mathrm{kPa}$ for case $\# 1$, respectively. The enhanced under-rib convection in both anode and cathode of case \#2 decreases the pressure drop, which also contributes to the performance by reducing the power consumption of air blower. 


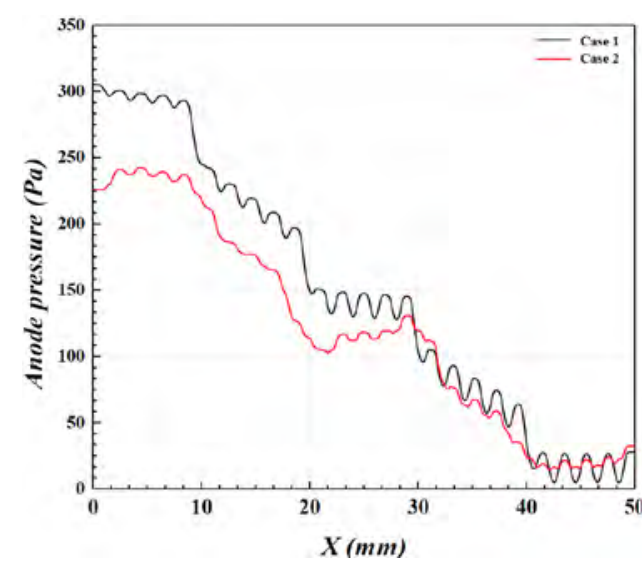

(a) Anode side

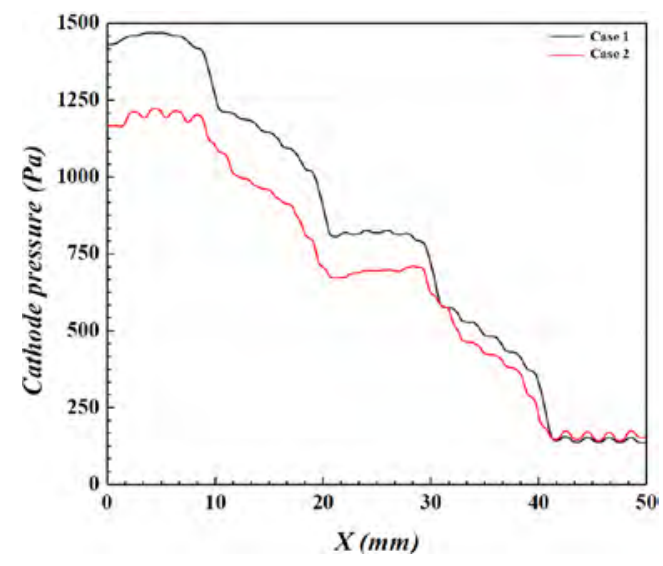

(b) Cathode side

Fig. 6. The comparison of the total pressures between the case \#1 and case \#2 at $I_{\text {ave }}=0.6 \mathrm{~A} / \mathrm{cm}^{2}$; (a) Anode side; (b) Cathode side.

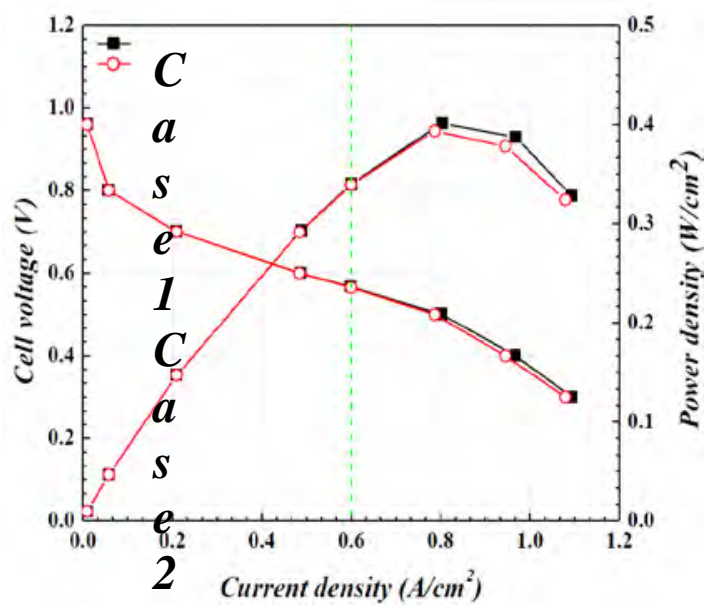

Fig. 7. The comparison of the polarization and power density curves between the case \#1 and case \#2.

To verify the maximization of power density among the performance-related parameters, the comparison of the polarization and power density curves between the case \#1 and case \#2 is given in Fig. 7. For the current density lower than $0.6 \mathrm{~A} / \mathrm{cm}^{2}$, the cell voltage and power density is independent of serpentine flow-field with and without sub-channel. For the current density greater than $0.6 \mathrm{~A} / \mathrm{cm}^{2}$, the cell voltages and power densities of case \#1 and case \#2 differ, the differences increase with the decreasing current density.

\section{Conclusions}

This study presents numerical analysis-based design of the serpentine flow field patterns to stimulate under-rib convection by adding sub-channel for improving the PEMFC performance. In the case of the case \#2, under-rib convection flow from channel to the adjacent rib and then flow from the inlet channel to the adjacent outlet channel, and liquid water gathers and discharges into the sub-channel. Through the present numerical analysis-based design, the serpentine flow field with sub-channel enhances the performances of pressure drop, discharge of liquid water, and uniformities of current density. 


\section{Acknowledgements}

This research was supported by Basic Science Research Program through the National Research Foundation of Korea (NRF) funded by the Ministry of Education, Science and Technology (No. 2009-0080496).

\section{References}

[1] F. Barbir, PEM Fuel Cells: Theory and Practice, Elsevier Academic Press, 2005.

[2] T. Kanezaki, X. Li and J.J. Baschuk, Cross-leakage flow between adjacent flow channels in PEM fuel cells, J. Power Sources 162, 2006, pp. 415 - 425.

[3] J.H. Nam, K.J. Lee, S.Sohn, C.H. Kim, Multi-pass serpentine flow-fields to enhance under-rib convection in polymer electrolyte membrane fuel cells: Design and geometrical characterization, J. Power Sources 188, 2009, pp. 14 - 23.

[4] D.H. Jeon, S. Greenway, S. shimpalee and J.W. Van Zee, The Effect of Serpentine Flow Field Designs on PEM Fuel Cell Performance, Int. J. Hydrogen Energy 33, 2008, pp. $1052-1066$

[5] CD-adapco, ES-PEMFC Methodology and Tutorial Manual, CD-adapco Group, 2008, http://www.adapco.com. 